\title{
ANALISIS CURAH HUJAN BULANAN DI KOTA AMBON MENGGUNAKAN MODEL HETEROSKEDASTISITAS: SARIMA-GARCH
}

Lexy Janzen Sinay, Ferry Kondo Lembang, Salmon Notje Aulele, Dominique Mustamu

Jurusan Matematika, Universitas Pattimura

e-mail: lexyjz@gmail.com

DOI: 10.14710/medstat.13.1.68-79

\section{Article Info:}

Received: 16 April 2019

Accepted: 20 June 2020

Available Online: 27 June 2020

Keywords:

Ambon City,

Heteroscedasticity, Rainfall,

SARIMA-GARCH volatility

clustering

\begin{abstract}
Non-linear characteritics in rainfall allow volatility clustering. This condition occurs in Ambon City with seasonal rainfall patterns. The aims of this research are to find the best model and to forecast monthly rainfall in Ambon City using heteroscedasticity model. This research examines secondary data from BMKG for monthly rainfall data in Ambon City from January 2005 December 2018. The data is divided into two parts. First part, is called in-sample data, consist of data form January 2005 - December 2017. Second part, is called out-sample data, consist data from Januari 2018 - December 2018. The research used SARIMA-GARCH to model the data. The results are the $\operatorname{SARIMA}(1,0,1)(1,1,0)_{12}-$ $\operatorname{GARCH}(2,2)$ is the best model and the residual model satisfied assumptions of normality, white noise, and there is no ARCH effect. The MAPE value in simulation using in-sample data is $0.73 \%$. On the other side, the MAPE value of forecast results is $30 \%$.
\end{abstract}

\section{PENDAHULUAN}

Kota Ambon merupakan Ibukota Provinsi Maluku yang terletak di Pulau Ambon. Sebagai bagian dari Negara Kesatuan Republik Indonesia, kondisi iklim di kota Ambon memiliki kemiripan dengan wilayah-wilayah lain di Indonesia, yakni memiliki iklim tropis dengan dua musim (musim hujan dan musim kemarau). Hal ini dikarenakan, letak astronomis Kota Ambon yang berada di sekitar garis lintang $0^{\circ}$ (garis khatulistiwa). Selain itu, iklim di Kota Ambon juga dipengaruhi oleh kondisi geografisnya. Kota Ambon berada di Pulau Ambon yang berada di wilayah Kepulauan Maluku. Secara geografis, wilayah Pulau Ambon dikelilingi oleh perairan Laut Banda, Pulau Seram, Kepulauan Lease (Pulau Haruku, Pulau Saparua, dan Pulau Nusalaut) dan beberapa pulau yang berukuran kecil di wilayah Maluku Tengah. Kondisi tersebut turut mempengaruhi kondisi iklim di wilayah Kota Ambon.

Kondisi iklim di Kota Ambon dalam 10 tahun terakhir sulit untuk diprediksi setiap tahunnya. Hal ini ditunjukkan dengan intensitas curah hujan di wilayah Kota Ambon yang bervariasi serta sulit diprediksi. Kondisi tersebut dapat diamati pada tahun 2012 dan 2013, Kota Ambon mengalami curah hujan yang sangat tinggi yang mengakibatkan terjadi 
bencana alam seperti banjir dan tanah longsor yang menimbulkan korban jiwa maupun materi. Sedangkan, pada tahun 2014 dan 2015 Kota Ambon mengalami kondisi curah hujan yang sangat sedikit. Dampak dari kejadian ini adalah Kota Ambon mengalami penurunan debit air bersih dan bencana kebakaran hutan yang terjadi Kota Ambon. Oleh karena itu, diperlukan analisis yang akurat untuk memodelkan dan memprediksi jumlah curah hujan berdasarkan waktu.

Pemodelan curah hujan berdasarkan waktu diklasifikasikan dalam pemodelan hydrological time series yang difokuskan untuk memperoleh model terbaik dan peramalan. Penelitian tersebut umumnya menggunakan model Autoregressive Moving Average (ARMA) atau Autoregressive Integrated Moving Average (ARIMA) yang diperkenalkan oleh Box-Jenkins. Model-model tersebut didasarkan atas asumsi stasioner dalam mean (mean 0) maupun dalam variansi yang konstan. Berikut ini merupakan beberapa kajian tentang curah hujan di Kota Ambon menggunakan beberapa metode analisis time series. Pada tahun 2015, Sinay dan Aulele memodelkan curah hujan dan jumlah hari hujan di kota Ambon menggunakan model Vector Autoregression (VAR). Penelitian tersebut menggunakan data hasil pengamatan Stasiun Geofisika BMKG Ambon periode Januari 2005 - Desember 2014. Hasil penelitian tersebut hanya dapat digunakan untuk peramalan jangka pendek dan modelnya disarankan untuk memodelkan data curah hujan yang mengandung trend (Sinay \& Aulele, 2015). Kemudian, Sinay, Patty, dan Leleury (2016) memodelkan data curah hujan di Kota Ambon menggunakan metode Box-Jenkins. Penelitian tersebut berdasarkan data hasil pengamatan Stasiun Meteorologi BMKG Ambon periode Januari 2005 - Desember 2015. Hasil yang diperoleh adalah model ARIMA musiman merupakan model terbaik (Sinay, Patty \& Leleury, 2016). Pada tahun 2017, Kafara, Rumlawang, dan Sinay menganalisis data yang digunakan pada penelitian sebelumnya (Sinay \& Aulele, 2015), namun metode yang digunakan berbeda. Penelitian tersebut menggunakan model Seasonal Autoregressive Integrated Moving Average (SARIMA) untuk menganalisis data curah hujan di Kota Ambon (Kafara, Rumlawang \& Sinay, 2017). Kemudian pada tahun 2017, Sinay, Pentury, dan Anakotta meng-update data yang digunakan pada penelitian sebelumnya (Sinay, Patty \& Leleury, 2016) menjadi periode Januari 2005 - Desember 2016 dan menganalisis data tersebut menggunakan metode Holt-Winters. Hasil yang diperoleh, model yang baik untuk peramalan adalah model musiman (Sinay, Pentury \& Anakotta, 2107). Berdasarkan kajian dari beberapa penelitian di atas, model time series yang tepat untuk memodelkan data curah hujan di Kota Ambon adalah model musiman.

Pengamatan dan analisis tentang curah hujan sangat kompleks yang melibatkan kondisi ruang dan waktu, sehingga data curah hujan dapat dikelompokkan sesuai ruang dan waktu. Umumnya, data curah hujan bersumber dari sebuah stasiun pengamatan pada wilayah tertentu dan disajikan dalam bentuk data time series baik itu harian maupun bulanan. Umumnya, data tersebut dapat dimodelkan secara linier, namun model tersebut belum dapat menjelaskan karakteristik non linier dari data curah hujan cukup kuat, misalnya terdapat komponen musiman dalam data curah hujan (Borthakur \& Baruah, 2016). Karakteristik non linier dalam curah hujan memungkinkan terjadinya klaster volatilitas (time varying variance), yaitu perubahan curah hujan yang lebat sering diikuti oleh perubahan hujan yang lebat dalam kurun waktu tertentu, demikan juga sebaliknya (Laux, et al., 2011) dan (Yusof \& Kane, 2013). Karakteristik yang juga dimiliki oleh curah hujan adalah memiliki distribusi kemiringan yang tinggi (highly skewed) (Villarini, Smith \& Napolitano, 2010). Selain itu, dalam penelitian sebelumnya, Wang, dkk (2005) memverifikasi adanya conditional heteroscedasticity dalam residual dari model linier 
proses streamflow (harian dan bulanan), dimana efek Autoregressive Heteroskedasticity $(\mathrm{ARCH})$ sepenuhnya disebabkan oleh variasi musiman dalam variansi untuk streamflow bulanan, sedangkan variasi musiman dalam variansi hanya menjelaskan sebagian efek ARCH untuk streamflow harian. Dengan demikian, diperlukan metode analisa data time series yang dapat menjelaskan karakteristik data curah hujan, yakni mengandung heteroskedastisitas dan tidak berdistribusi normal.

Berdasarkan kajian sebelumnya, curah hujan di Kota Ambon mengandung komponen musiman, yang mana cenderung memiliki karakteristik non linear, sehingga mengindikasikan adanya kejadian klaster volatilitas (terjadinya heteroskedastisitas). Berbeda dengan penelitian-penelitian sebelumnya, penelitian ini menganalisis data curah hujan di Kota Ambon dengan memperhatikan kondisi residual model. Oleh karena itu, penelitian ini menganalisis residual model musiman dari data curah hujan bulanan di Kota Ambon dengan menggunakan model Autoregressive Heteroskedasticity (ARCH) atau model Generalized ARCH (GARCH) yang dikembangkan oleh Engle (1982) dan Bollerslev (1986). Dengan demikian, tujuan dari penelitian adalah memodelkan data curah hujan bulanan di Kota Ambon menggunakan model heteroskedastisitas, dan menganalisa hasil ramalan berdasarkan model terpilih. Penelitian ini diharapkan menjadi solusi pemodelan data curah hujan bulanan di Kota Ambon.

\section{TINJAUAN PUSTAKA}

\subsection{Model Non Musiman: ARMA/ARIMA}

Autoregressive Moving Average (ARMA) adalah model hibrida dari proses autoregressive (AR) dan proses moving average (MA) yang pertama kali diperkenalkan oleh G. E. P. Box. Model $A R M A(p, q)$ dapat ditulis dalam persamaan berikut ini

$$
\begin{aligned}
X_{t}= & \phi_{1} X_{t-1}+\phi_{2} X_{t-2}+\ldots+\phi_{p} X_{t-p}+\varepsilon_{t}+\theta_{1} \varepsilon_{t-1} \\
& +\theta_{2} \varepsilon_{t-2}+\ldots+\theta_{q} \varepsilon_{t-q}
\end{aligned}
$$

dengan $\phi_{1}, \phi_{2}, \ldots, \phi_{p}$ adalah koefisien autoregressive, $\theta_{1}, \theta_{2}, \ldots, \theta_{q}$ adalah koefisien moving average, dan $\varepsilon_{t}$ tidak tergantung pada $X_{t-1}, X_{t-2}, X_{t-3}, \ldots$. Persamaan (1), oleh Box-Jenkins, dapat dinyatakan dalam bentuk $\operatorname{ARMA}(p, q)$. Menggunakan operator backshift, persamaan (1) dapat dinyatakan seperti berikut ini

$$
\phi(B) X_{t}=\theta(B) \varepsilon_{t}
$$

dengan

$$
\begin{aligned}
& \phi(B)=1-\phi_{1} B-\phi_{2} B^{2}-\ldots-\phi_{p} B^{p} \\
& \theta(B)=1+\theta_{1} B+\theta_{2} B^{2}+\ldots+\theta_{q} B^{q}
\end{aligned}
$$

Keterangan: Proses $X_{t}$ dikatakan sebagai $A R(p)$ jika $\theta(B)=1$, atau dikatakan sebagai $M A(q)$ jika $\phi(B)=1$.

Box dan Jenkins (1976) memperkenalkan model Autoregressive Integrated Moving Average (ARIMA) dan peramalan menggunakan data univariate time series. Model ARIMA merupakan perluasan dari model ARMA. Proses $X_{t}$ disebut sebagai proses $\operatorname{ARIMA}(p, d, q)$ jika $W_{t}=\nabla^{d} X_{t}=(1-B)^{d} X_{t}$ merupakan suatu proses $\operatorname{ARMA}(p, q)$ yang stasioner. Secara umum, modelnya dapat ditulis seperti berikut

$$
\phi(B)(1-B)^{d} X_{t}=\theta(B) \varepsilon_{t}
$$

dengan $d$ merupakan jumlah diferensi hingga data time series menjadi stasioner. 


\subsection{Model Musiman: SARMA/SARIMA}

Musiman merupakan fenomena yang terjadi pada data time series. Fenomena tersebut membentuk pola tertentu pada selang waktu tertentu dan berulang pada periode waktu (musim) berikutnya. Berikut ini diberikan model ARMA dan ARIMA musiman.

Bentuk umum model ARMA musiman (SARMA) diperlihatkan sebagai berikut

$$
\phi_{p}(B) \Phi_{P}\left(B^{s}\right) X_{t}=\theta_{q}(B) \Theta_{Q}\left(B^{s}\right) \varepsilon_{t}
$$

Sedangkan bentuk umum model ARIMA musiman (SARIMA) adalah

$$
\phi_{p}(B) \Phi_{P}\left(B^{s}\right)(1-B)^{d}\left(1-B^{s}\right)^{D} X_{t}=\theta q(B) \Theta_{Q}\left(B^{s}\right) \varepsilon_{t}
$$

dengan

$$
\begin{aligned}
& \phi_{p}(B)=1-\phi_{1} B-\phi_{2} B^{2}-\ldots-\phi_{p} B^{p} \\
& \Phi_{p}\left(B^{s}\right)=1-\Phi_{1} B-\Phi_{2} B^{2}-\ldots-\Phi_{P} B^{P s} \\
& \theta_{q}(B)=1-\theta_{1} B-\theta_{2} B^{2}-\ldots-\theta_{q} B^{q} \\
& \Theta_{Q}\left(B^{s}\right)=1-\Theta_{1} B-\Theta_{2} B^{2}-\ldots-\Theta_{Q} B^{Q s}
\end{aligned}
$$

$B$ merupakan operator backshift, $d=$ jumlah diferensi non-musiman, dan $D=$ jumlah diferensi musiman. Diferensi musiman dengan periode $s$ untuk deret $\left\{X_{t}\right\}$ dinotasikan dengan $\nabla_{S} X_{t}$ dan didefinisikan sebagai:

$$
\nabla_{s} X_{t}=X_{t}-X_{t-s}
$$

Sebuah proses $\left\{X_{t}\right\}$ dikatakan sebagai model musiman $\operatorname{SARIMA}(p, d, q)(P, D, Q)_{s}$ atau $\operatorname{ARIMA}(p, d, q)(P, D, Q)_{s}$ [persamaan (5)], jika memenuhi

$$
Y_{t}=\nabla^{d} \nabla_{s}^{D} X_{t}
$$

Dengan $\nabla^{d}=(1-B)^{d}$ dan $\nabla_{S}^{D}=(1-B s)^{D}$. Jika $d=0$ dan $D=0$ maka memenuhi model $S A R M A(p, q)(P, Q)_{s}$ atau $A R M A(p, q)(P, Q)_{s}$ [persamaan (4)].

\subsection{Model Heteroskedastisitas: GARCH}

Model Generalized Autoregressive Conditional Heteroskedasticity (GARCH) diperkenalkan oleh Bollerslev (1986). Model GARCH merupakan hasil generalisasi model ARCH yang diperkenalkan oleh Engle (1982).

Misalkan $r_{t}$ (menyatakan nilai $\log$ return dari aset pada waktu $t$ ). Didefinisikan nilai mean bersyarat

$$
\mu_{t}=E\left(r_{t} \mid \mathcal{F}_{t-1}\right) \text { dan } \sigma_{t}^{2}=\operatorname{var}\left(r_{t} \mid \mathcal{F}_{t-1}\right)=E\left(\left(r_{t}-\mu_{t}\right)^{2} \mid \mathcal{F}_{t-1}\right)
$$

dengan $\mathcal{F}_{t-1}$ menyatakan semua informasi sampai dengan waktu $(t-1)$, yang merupakan suatu fungsi linier (dari return) sampai waktu $(t-1)$.

Umumnya, model mean dapat dinyatakan sebagai

$$
r_{t}=\mu_{t}+\varepsilon_{t}, E\left(r_{t} \mid \mathcal{F}_{t-1}\right)=0 \text {, untuk setiap } t \text {. }
$$

$\varepsilon_{t}$ merupakan martingale difference sequence (MDS). Dengan demikian, $\varepsilon_{t}=r_{t}-\mu_{t}$ (mean corrected $\log$ return). $\varepsilon_{t}$ dikatakan mengikuti model $\operatorname{GARCH}(p, q)$ jika

$$
\varepsilon_{t}=\sigma_{t} z_{t}
$$


dan variansi

$$
\sigma_{t}^{2}=\omega+\sum_{i=1}^{p} \alpha_{i} \varepsilon_{t-i}^{2}+\sum_{j=1}^{q} \beta_{j} \sigma_{t-j}^{2}
$$

Dengan $z_{t} \sim \operatorname{IID}(0,1)$ (sering diasumsikan berdistribusi $N(0,1)$ atau suatu Gaussian white noise). Sifat-sifat koefisien $\operatorname{GARCH}(p, q)$ adalah $\omega>0, \alpha_{i} \geq 0$ untuk $i=1,2, \ldots, p, \beta_{j} \geq$ 0 untuk $j=1,2, \ldots, q$, dan $\sum_{i=1}^{q} \alpha_{i}+\sum_{j=1}^{p} \beta_{j}<1$. Jika $q=0$, maka diperoleh model $\operatorname{ARCH}(p)$. Jika $p=q=0$, maka diperoleh model white noise.

Persamaan (6) dapat dinyatakan sebagai

$$
\sigma_{t}^{2}=\omega+\alpha(B) \varepsilon_{t}^{2}+\beta(B) \sigma_{t}^{2},
$$

menghasilkan,

$$
(1-\beta(B)) \sigma_{t}^{2}=\omega+\alpha(B) r_{t}^{2}
$$

dengan $\alpha(B)$ dan $\beta(B)$ adalah polinomial-polinomial dalam operator backshift $B$ seperti berikut ini

$$
\alpha(B)=\alpha_{1} B+\ldots+\alpha_{q} \alpha B^{q}
$$

dan

$$
\beta(B)=\beta_{1} B+\ldots+\beta_{p} B^{p}
$$

\section{METODE PENELITIAN}

\subsection{Data}

Data yang digunakan dalam penelitian ini adalah data sekunder yang bersumber dari Badan Meteorologi Klimatologi dan Geofisika (BMKG) merupakan hasil pengamatan Stasiun Meteorologi Klas II Pattimura Ambon pada koordinat $03^{\circ} 42^{\prime} 25^{\prime \prime}$ LS $128^{\circ} 05^{\prime} 23^{\prime \prime}$ BT, dengan elevasi 15,4 m. Data tersebut merupakan data time series curah hujan bulanan di Kota Ambon, hasil pengamatan pada periode Januari 2005 - Desember 2018. Untuk keperluan analisis, data tersebut dibagi menjadi 2 periode. Data pertama, periode Januari 2005 - Desember 2017 digunakan sebagai sampel untuk pemodelan dan peramalan (data in-sample). Sedangkan data berikut adalah periode Januari 2018 - Desember 2018 digunakan sebagai data pembanding hasil peramalan berdasarkan model terbaik (data outsample).

\subsection{Pemodelan SARIMA}

Prosedur analisis pemodelan SARIMA-GARCH

(1) Identifikasi stasioner, seasonal, dan orde model SARIMA Identifikasi stasioner dalam mean menggunakan uji akar unit: Augmented DickeyFuller (ADF) dan Kwiatkowski, Phillips, Schmidt and Shin (KPSS). Identifikasi data stasioner dalam variansi, data terdapat efek musiman, dan orde model SARIMA menggunakan line plot dan plot ACF/PACF.

(2) Estimasi model SARIMA menggunakan Maximum Likelihood Estimator (MLE) dan memperhatikan signifikansi parameter menggunakan statistik uji $t$.

(3) Seleksi model SARIMA menggunakan nilai-nilai kriteria informasi: AIC, AICc, dan BIC. 
(4) Analisis residual model SARIMA terpilih: uji normalitas menggunakan statistik uji Jarque-Bera, uji white noise menggunakan statistik uji Ljung-Box, dan pemeriksaan efek ARCH.

(5) Menggunakan residual model SARIMA untuk pemodelan GARCH

(6) Estimasi model GARCH

(7) Seleksi model GARCH menggunakan nilai-nilai kriteria informasi: AIC dan BIC.

(8) Analisis model SARIMA-GARCH terutama uji asumsi residual: uji normalitas menggunakan statistik uji Jarque-Bera, uji white noise menggunakan statistik uji Ljung-Box, dan pemeriksaan efek ARCH. Hal ini bertujuan untuk memeriksa apakah model tersebut sudah memenuhi asumsi-asumsi yang diuji dan sebagai dasar pengambilan keputusan model terbaik (selain menggunakan kriteria informasi).

(9) Simulasi dan peramalan. Simulasi yang dimaksud adalah mengevaluasi curah hujan berdasarkan data aktual dan model fitted untuk memperoleh nilai-nilai MAE, RMSE, dan MAPE, sedangkan peramalan untuk mengetahui besaran curah hujan bulanan dalam beberapa kurun waktu ke depan.

\section{HASIL DAN PEMBAHASAN}

\subsection{Karakteristik Data}

Deskripsi statistika data aktual curah hujan di Kota Ambon (data in-sample) dirangkum dalam Tabel 1. Hasil yang diperlihatkan pada Tabel 1 merupakan deskripsi dari hasil pengamatan curah hujan bulanan di Kota Ambon selama 156 bulan. Rata-rata curah hujan bulanan di Kota Ambon termasuk dalam kategori curah hujan tinggi, dengan nilai deviasi bakunya yang relatif tinggi. Hal ini menggambarkan variasi curah hujan relatif besar yang terjadi setiap bulan di Kota Ambon. Selain itu, Tabel 1 memperlihatkan hasil uji normalitas yang menyatakan bahwa data curah hujan bulanan di Kota Ambon tidak berdistribusi normal dan kurvanya bersifat leptokurtik karena nilai kurtosis lebih dari 3. Hal ini menunjukkan bahwa karaktersitik data tersebut memiliki kecenderungan terjadi kejadian ekstrem.

Tabel 1 Deskripsi Statistika Data Aktual Curah Hujan Bulanan Di Kota Ambon Periode Januari 2005 - Desember 2017

\begin{tabular}{lrlrll}
\hline Uk uran Pemusatan dan Dispersi & \multicolumn{2}{l}{ Uk uran Keruncingan } & \multicolumn{2}{l}{ Uji Normalitas } & \\
\hline Mean & 312,1603 & Kurtosis & 8,414 & Jarque-Bera & 322,78 \\
Maksimum & 1923 & & p value & 0,0000 \\
Minimum & 3 & & & \\
Deviasi Baku & 329,0676 & & & & \\
\hline
\end{tabular}

\subsection{Data Aktual Curah Hujan vs Data Transformasi Logaritma Natural}

Bagian ini membahas tentang hasil analisis stasioneritas data dan identifikasi musiman. Analisis stasioneritas data dilakukan secara visual maupun non visual, sedangkan identifikasi musiman dilakuan secara visual. Analisis stasioneritas dan identifikasi musiman dilakukan secara visual menggunakan line plot, plot ACF/PACF. Sedangkan, analisis stasioneritas data secara non visual menggunakan uji ADF dan uji KPSS.

Secara visual, data aktual curah hujan bulanan di Kota Ambon diperlihatkan pada Gambar 1. Line plot memperlihatkan curah hujan di Kota Ambon mengalami fluktuasi dengan variasi yang sangat besar. Hal ini menunjukkan data tersebut tidak stasioner dalam 
variansi. Line plot juga memperlihatkan tidak terdapat trend dalam data, namun mengindikasikan adanya pola musiman (Gambar 1a). Hasil tersebut didukung oleh analisis plot ACF yang polanya tidak meluruh secara lambat menuju 0 , namun membentuk sinusoidal (Gambar 1b). Selain itu, line plot memperlihatkan curah hujan yang relatif rendah terjadi secara berurutan pada bulan-bulan tertentu. Demikian juga sebaliknya, kejadian hujan yang relatif tinggi terjadi pada bulan-bulan tertentu secara berurutan. Hal ini mengindikasikan adanya klaster volatilitas pada data curah hujan bulanan di Kota Ambon.
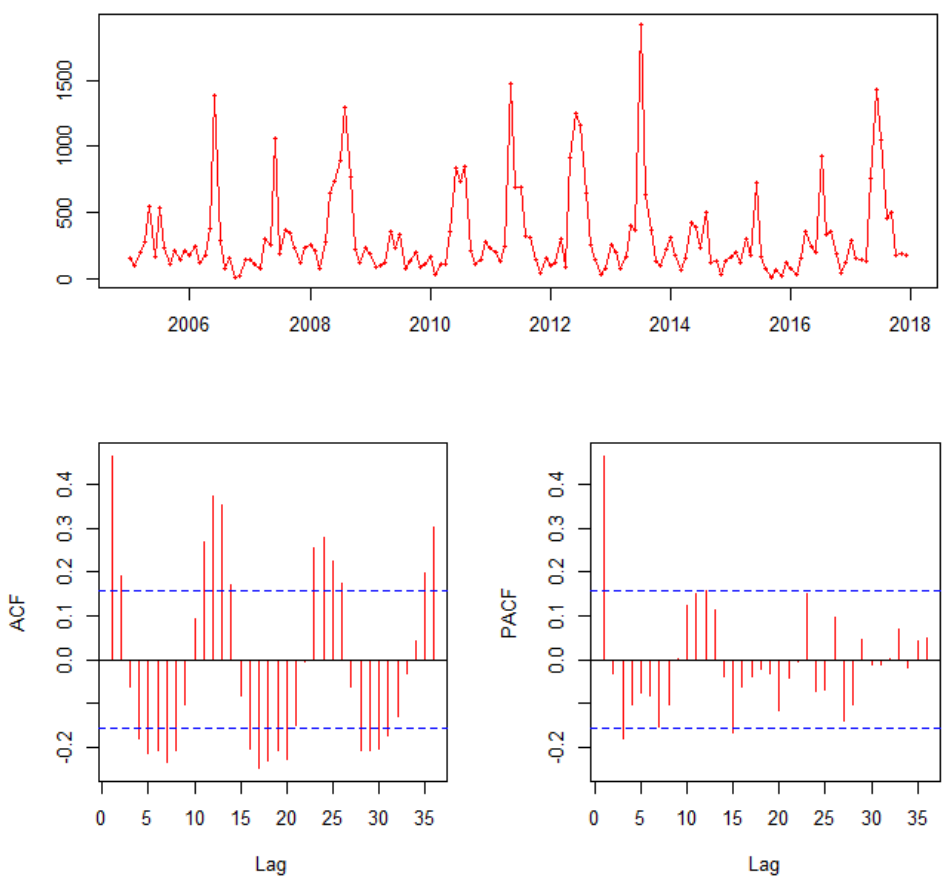

Gambar 1 Plot Data Aktual: a. Line Plot; b. Plot ACF; c. Plot PACF
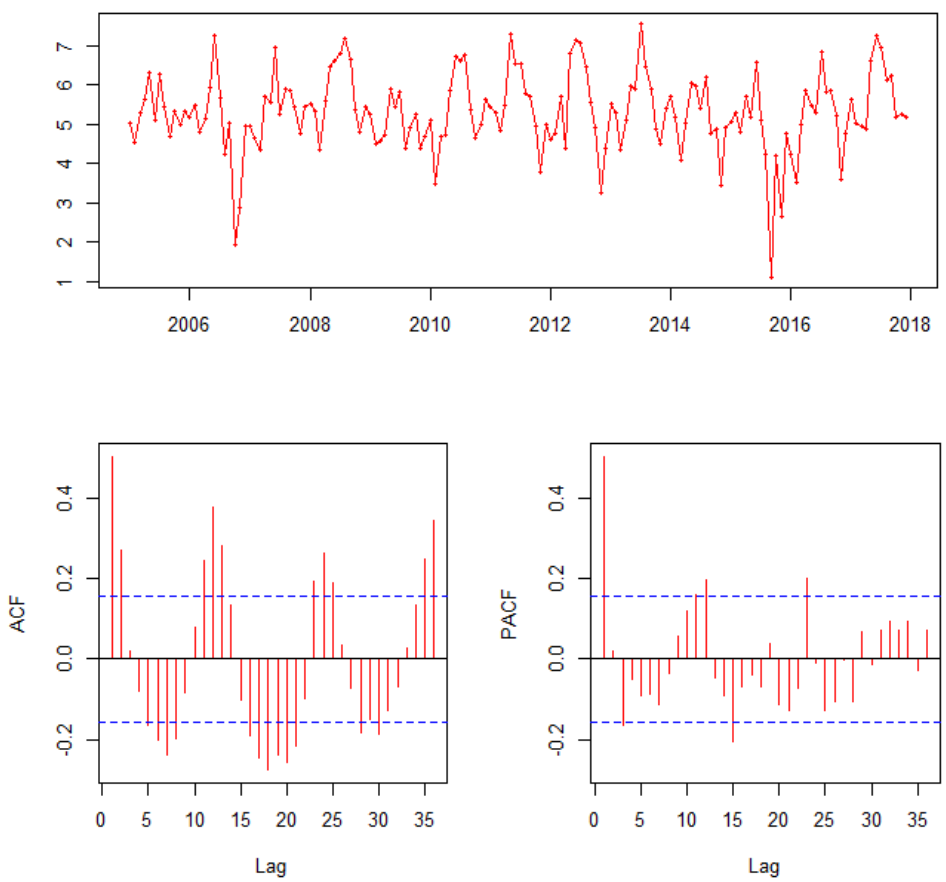

Gambar 2 Plot Data Transformasi Logaritma: a. Line Plot, b. Plot ACF, c. Plot PACF 
Untuk mengatasi ketidakstasioneran data dalam variansi, maka digunakan transformasi Box-Cox. Hasil identifikasi data diperoleh bahwa nilai pembulatan estimasi parameter transformasi adalah 0. Oleh karena itu, transformasi yang digunakan adalah transformasi logaritma natural (logaritma). Hasil transformasi logaritma dari data aktual curah hujan diperlihatkan pada Gambar 2. Berdasarkan Gambar 2a, line plot data tersebut memperlihatkan variasi data relatif lebih kecil. Hal ini mengindikasikan data sudah stasioner dalam variansi. Di samping itu, hasil yang diperlihatkan oleh line plot dan plot ACF menyatakan bahwa data hasil transformasi sudah tidak terdapat trend, namun terdapat pola musiman.

Tabel 2 Analisis Stasioneritas: Data Aktual vs Data Transformasi Logaritma Periode Januari 2005 - Desember 2017

\begin{tabular}{ccccc}
\hline \multirow{2}{*}{ Jenis Uji } & \multicolumn{2}{c}{ Aktual } & \multicolumn{2}{c}{ Transformasi Logaritma } \\
\cline { 2 - 5 } & Statistik Uji & p-value & Statistik Uji & p-value \\
\hline ADF & $-7,476419$ & 0,0000 & $-7,120870$ & 0,0000 \\
KPSS & 4,38 & 0,01 & 0,673 & 0,1 \\
\hline
\end{tabular}

Hasil pemeriksaan stasioneritas data aktual curah hujan dan data transformasi logaritma diperlihatkan pada Tabel 2. Hasil uji ADF pada taraf kepercayaan 95\% menyatakan bahwa data aktual tidak mengandung akar unit (stasioner) karena $p$ value lebih kecil dari taraf signifikansi $\alpha=5 \%$. Hasil tersebut kontradiksi dengan hasil uji KPSS yang menyatakan data tersebut tidak stasioner karena $p$ value lebih kecil dari taraf signifikansi $\alpha$ $=5 \%$. Di sisi lain, hasil uji ADF dan hasil uji KPSS data transformasi logaritma menunjukkan hasil yang sama, yakni data hasil transformasi logaritma sudah stasioner pada taraf kepercayaan $95 \%$.

\subsection{Model SARIMA}

Berdasarkan hasil analisis sebelumnya, data yang digunakan untuk menganalisis model SARIMA adalah data transformasi logaritma. Hasil identifikasi orde model SARIMA dengan memperhatikan prinsip parsimony diperoleh model SARIMA $(1,0,1)(1,1,0)_{12}$. Model tersebut merupakan model yang memiliki koefisienkoefisien yang signifikan dengan nilai-nilai AIC, AICc, dan BIC yang paling kecil, secara berturut-turut, yakni 0,$81 ; 0,825$; dan $-0,13$. Rangkuman hasil estimasi model tersebut diperlihatkan pada Tabel 3 .

Tabel 3 Hasil Estimasi Parameter Model SARIMA $(1,0,1)(1,1,0)_{12}$

\begin{tabular}{ccc}
\hline Variabel & Koefisien & Standard Error \\
\hline AR(1) & 0,7971 & 0,0891 \\
SAR(1) & $-0,4976$ & 0,0771 \\
MA(1) & $-0,4924$ & 0,1184 \\
\hline
\end{tabular}

Hasil analisis residual model SARIMA $(1,0,1)(1,1,0)_{12}$ dirangkum pada Tabel 4. Uji asumsi normalitas menggunakan statistik uji Jarque-Bera menyatakan bahwa residual model SARIMA $(1,0,1)(1,1,0)_{12}$ tidak berdistribusi normal pada taraf kepercayaan $95 \%$. Hasil uji Ljung-Box pada residual menyatakan bahwa tidak terjadi korelasi serial pada residual (residual bersifat white noise). Sedangkan hasil uji Ljung-Box pada residual kuadrat terjadi korelasi serial. Kemudian hasil uji heteroskedastisitas menggunakan statistik uji ARCH-LM menunjukkan bahwa pada taraf kepercayaan 95\% terjadi heteroskedastisitas atau terdapat efek ARCH dalam model SARIMA $(1,0,1)(1,1,0)_{12}$. 
Tabel 4 Uji Asumsi Residual Model SARIMA $(1,0,1)(1,1,0)_{12}$

\begin{tabular}{lllcc}
\hline \multicolumn{1}{c}{ Jenis Uji } & \multicolumn{1}{c}{ Data } & \multicolumn{2}{c}{ Statistik Uji } & p-value \\
\hline Jarque-Bera & Residual & $\chi^{2}$ & 24,422 & $4,976 \times 10^{-6}$ \\
Ljung-Box & Residual & $Q(10)$ & 7,0925 & 0,7167 \\
Ljung-Box & Residual & $Q(15)$ & 13,849 & 0,5370 \\
Ljung-Box & Residual & $Q(20)$ & 16,106 & 0,7101 \\
Ljung-Box & Residual Kuadrat & $Q(10)$ & 8,8198 & 0,5493 \\
Ljung-Box & Residual Kuadrat & $Q(15)$ & 36,095 & 0,0017 \\
Ljung-Box & Residual Kuadrat & $Q(20)$ & 40,393 & 0,0045 \\
ARCH-LM & Residual & $T R^{2}$ & 86,57 & 0,0000 \\
\hline
\end{tabular}

\subsection{Model GARCH}

Bagian ini membahas tentang analisis model GARCH berdasarkan model SARIMA $(1,0,1)(1,1,0)_{12}$. Data yang digunakan untuk analisis model GARCH adalah data residual model SARIMA $(1,0,1)(1,1,0)_{12}$. Berdasarkan hasil seleksi model diperoleh bahwa model GARCH $(2,2)$ merupakan model yang paling sederhana dengan nilai AIC dan BIC yang terkecil, secara terurut, yakni 2,463 dan 2,58.

Tabel 5 Hasil Estimasi Parameter Model GARCH(2,2)

\begin{tabular}{ccc}
\hline Variabel & Koefisien & Standard Error \\
\hline$\mu$ & 0,02 & 0,0052 \\
$\omega$ & 0,1203 & 0,0552 \\
$\alpha_{1}$ & 0,0102 & 0,0055 \\
$\alpha_{2}$ & 0,4733 & 0,1959 \\
$\beta_{1}$ & $1 \times 10^{-08}$ & 0,1215 \\
$\beta_{2}$ & 0,4412 & 0,2230 \\
\hline
\end{tabular}

Hasil estimasi parameter model $\operatorname{GARCH}(2,2)$ dirangkum pada Tabel 5. Tabel tersebut memperlihatkan bahwa koefisien-koefisien yang diperoleh sudah memenuhi sifatsifat model GARCH umumnya, yakni bernilai positif serta jumlah dari semua koefisien $\alpha$ dan $\beta$ bernilai kurang dari 1 .

\subsection{Analis is Model SARIMA $(1,0,1)(1,1,0)_{12}-\operatorname{GARCH}(2,2)$}

Berdasarkan hasil analisis pada bagian sebelumnya, maka diperoleh model SARIMA $(1,0,1)(1,1,0)_{12}-\operatorname{GARCH}(2,2)$ sebagai model terbaik untuk memodelkan data curah hujan bulanan di Kota Ambon. Hal ini didasarkan atas hasil analisis residual model SARIMA $(1,0,1)(1,1,0)_{12}-\operatorname{GARCH}(2,2)$ yang diperlihatkan pada Tabel 6 . Tabel tersebut memperlihatkan uji asumsi residual model $\operatorname{SARIMA}(1,0,1)(1,1,0)_{12}$ GARCH $(2,2)$, yakni uji normalitas, uji autokorelasi (korelasi serial), dan uji heteroskedastistias (efek ARCH).

Uji normalitas yang diperlihatkan pada Tabel 6, menggunakan statistik uji JarqueBera menyatakan bahwa residual model $\operatorname{SARIMA}(1,0,1)(1,1,0)_{12}-\operatorname{GARCH}(2,2)$ berdistribusi normal pada taraf kepercayaan 95\%. Hasil uji Ljung-Box (diwakili oleh lag $10,15,20)$ menunjukkan bahwa pada taraf kepercayaan $95 \%$ residual maupun kuadrat residual tidak mengalami korelasi serial (autokorelasi). Hal ini berarti bahwa residual 
bersifat white noise. Kemudian, hasil uji ARCH-LM menyatakan bahwa residual model $\operatorname{GARCH}(2,2)$ tidak terdapat efek ARCH atau tidak terjadi heteroskedastisitas pada taraf kepecayaan 95\%. Dengan demikian, model $\operatorname{SARIMA}(1,0,1)(1,1,0)_{12}-\operatorname{GARCH}(2,2)$ merupakan model terbaik yang memenuhi asumsi-asumsi pemodelan SARIMA dan GARCH.

Tabel 6 Uji Asumsi Residual Model SARIMA(1,0,1)(1,1,0) $12-\operatorname{GARCH}(2,2)$

\begin{tabular}{lllcc}
\hline \multicolumn{1}{c}{ Jenis Uji } & \multicolumn{1}{c}{ Data } & \multicolumn{2}{c}{ Statistik Uji } & p-value \\
\hline Jarque-Bera & Residual & $\chi^{2}$ & 0,3640 & 0,8336 \\
Ljung-Box & Residual & $Q(10)$ & 8,4367 & 0,5863 \\
Ljung-Box & Residual & $Q(15)$ & 13,4760 & 0,5656 \\
Ljung-Box & Residual & $Q(20)$ & 16,4499 & 0,6884 \\
Ljung-Box & Residual Kuadrat & $Q(10)$ & 15,1057 & 0,1283 \\
Ljung-Box & Residual Kuadrat & $Q(15)$ & 22,3506 & 0,0989 \\
Ljung-Box & Residual Kuadrat & $Q(20)$ & 31,3670 & 0,051 \\
ARCH-LM & Residual & $T R^{2}$ & 17,5042 & 0,1316 \\
\hline
\end{tabular}

Tabel 7 Ukuran Ketepatan Peramalan

\begin{tabular}{ccc}
\hline & In-Sample & Out-Sample \\
\hline MAE & 1,4625 & 130,7236 \\
RMSE & 2,1604 & 211,5961 \\
MAPE & 0,7375 & 30,0131 \\
\hline
\end{tabular}

Hasil simulasi menggunakan model $\operatorname{SARIMA}(1,0,1)(1,1,0)_{12}-\operatorname{GARCH}(2,2)$ diperoleh ukuran ketepatan peramalan yang diperlihatkan pada Tabel 7. Hasil simulasi tersebut diperoleh berdasarkan nilai-nilai fitted dan data in-sample. Hasil tersebut menunjukkan bahwa model $\operatorname{SARIMA}(1,0,1)(1,1,0)_{12}-\operatorname{GARCH}(2,2)$ merupakan model dengan tingkat keakuratan yang baik. Hal ini ditunjukkan oleh nilai-nilai MAE dan RMSE yang sangat kecil, serta nilai MAPE yang hanya $0,7 \%$ yang mengindikasikan bahwa hasil tersebut sangat akurat.

Hasil simulasi untuk ramalan curah hujan 12 bulan ke depan dengan data aktual di luar sampel (out-sample) memperlihatkan nilai-nilai MAE, RMSE, dan MAPE yang lebih besar dibandingkan data in-sample (Tabel 7). Hasil yang diperoleh pada Tabel 7 menunjukkan bahwa nilai MAPE yang diperoleh adalah 30\%. Hasil tersebut mengindikasikan bahwa hasil peramalan data out-sample masuk dalam kategori wajar (reasonable). Secara visual, perbandingan data out-sample dengan hasil ramalan diperlihatkan pada Gambar 3.

Grafik (line plot) data aktual (out-sample) ditunjukkan oleh garis tegas berwarna biru, sedangkan hasil ramalan ditunjukkan oleh garis putus-putus berwarna merah (Gambar 3). Hasil yang diperlihatkan pada Gambar 3 menunjukkan bahwa pola kedua grafik memiliki kemiripan yakni hujan lebat tidak terjadi di awal dan kahir tahun, namun terjadi pada pertengahan tahun. Hal ini menunjukkan bahwa hasil ramalan mengikuti pola musiman curah hujan yang terjadi di Kota Ambon. Berdasarkan Gambar 3, jumlah curah hujan yang diperoleh hasil ramalan lebih tinggi dibandingkan data aktual. Perbedaan yang signifikan antara hasil ramalan dan data aktual terjadi pada bulan Mei, Juni, Juli, Agustus, 
dan Oktober, dimana selisihnya berada pada selang $144-617 \mathrm{~mm}$. hal ini sangat mempengaruhi nilai MAE, RMSE, dan MAPE data out-sample (Tabel 7). Di sisi lain, hasil ramalan berada dalam batas kewajaran terjadi pada bulan Januari, Maret, April, September, dan November dimana selisihnya berada dalam selang $21-70 \mathrm{~mm}$. Sementara itu, bulan Februari, April, dan Desember hasil ramalan akurat karena selisihnya tidak melebihi 10 $\mathrm{mm}$.

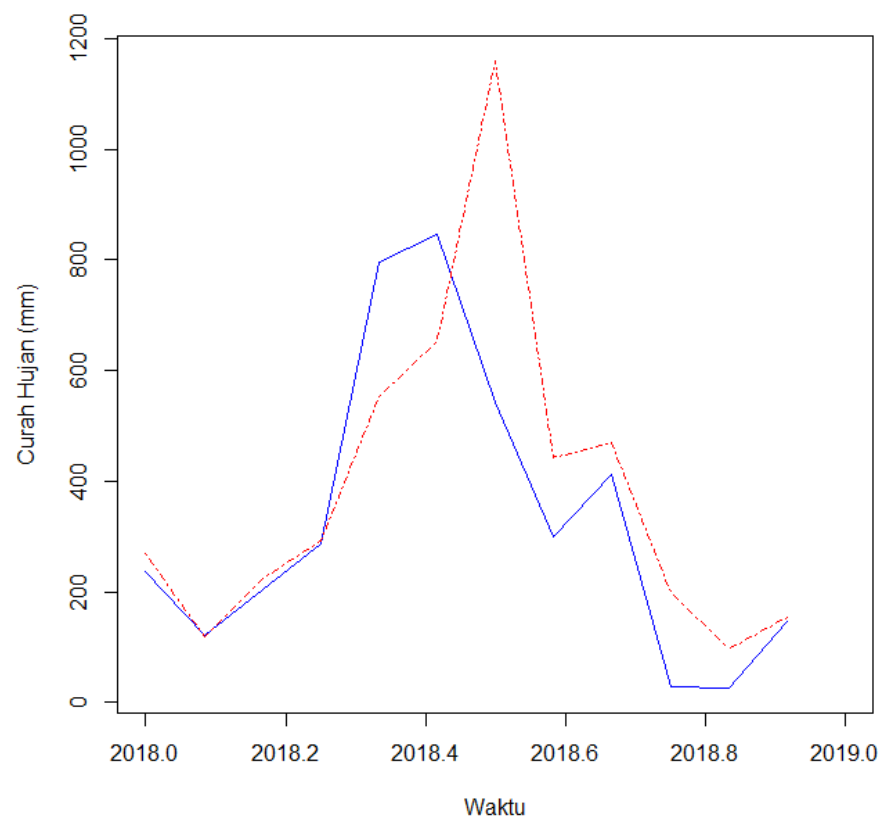

Gambar 3 Plot Data Aktual vs Hasil Ramalan untuk Periode Januari 2018 - Desember 2018

\section{KESIMPULAN}

Kajian dan analisis sebelumnya menunjukkan bahwa curah hujan di Kota Ambon mengandung komponen musiman dan terjadi klaster volatilitas (heteroskedastis). Model time series berbasis musiman belum cukup menggambarkan karakteristik data yang mengandung heteroskedastisitas. Hal ini ditunjukkan oleh hasil analisis residual SARIMA $(1,0,1)(1,1,0)_{12}$ yang belum memenuhi beberapa asumsi seperti asumsi normalitas, heteroskedastisitas, dan autokorelasi. Salah satu solusi untuk mengatasi hal tersebut adalah memodelkan kembali residual model $\operatorname{SARIMA}(1,0,1)(1,1,0)_{12}$ menggunakan model heteroskedastisitas. Berdasarkan hasil pembahasan di atas diperoleh SARIMA $(1,0,1)(1,1,0)_{12}-\operatorname{GARCH}(2,2)$ sebagai model terbaik. Model tersebut memenuhi semua kriteria dan uji asumsi dalam pemodelan SARIMA-GARCH.

Hasil peramalan menggunakan model $\operatorname{SARIMA}(1,0,1)(1,1,0)_{12}-\operatorname{GARCH}(2,2)$ sangat akurat untuk data in-sample, karena memiliki nilai-nilai MAE, RMSE, dan MAPE yang relatif kecil. Namun untuk data out-sample, nilai MAE, RMSE yang dihasilkan cukup besar dibandingkan data in-sample. Berdasarkan nilai MAPE hasil ramalan yakni sebesar $30 \%$, maka hasil ramalan menggunakan model $\operatorname{SARIMA}(1,0,1)(1,1,0)_{12}-\operatorname{GARCH}(2,2)$ diklasifikasikan dalam kategori wajar.

\section{DAFTAR PUSTAKA}

Bollerslev, T. 1986. Generalized Autoregressive Conditional Heteroskedasticity. Journal of Econometrics, Vol. 31, hal 307-327. 
Bollerslev, T., Chou, R. Y., dan Kroner, K. F. 1992. ARCH Modeling in Finance (A Review of the Theory and Empirical Evidence). Journal of Econometrics, Vol. 52, hal 5-59.

Borthakur, G. G. dan Baruah, S. P. 2016. Modeling Seasonality of Rainfall by Nonlinear curve Fitting to Monthly Rainfall Time Series of Jorhat. International Journal of Computer Applications, Vol. 149, No. 9, hal 6-13.

Box, G. E. P. dan Jenkins, G. M. 1976. Time Series Analysis: Forecasting and Control. Revised ed. San Fransisco, CA: Holden-Day.

Engle, R. F. 1982. Autoregressive Conditional Heteroscedasticity with Estimates of the Variance of United Kingdom Inflation. Econometrica, Vol. 50, No. 4, hal 9871007.

Fuller, W. A. 1996. Introduction to Statistical Time Series, New York: John Willey Sons.

Jarque, C. M. dan Bera, A. K. 1980. Efficient Test for Normality, Homoscedasticity and Serial Independence of Residuals. Economic Letters, Vol. 6, No. 3, hal 255-259.

Kafara, Z., Rumlawang, F. Y., dan Sinay, L. J. 2017. Peramalan Curah Hujan Dengan Pendekatan Seasonal Autoregressive Integrated Moving Average (SARIMA) (Studi Kasus: Curah Hujan Bulanan di Kota Ambon, Provinsi Maluku). Barekeng: Jurnal Ilmu Matematika dan Terapan, Vol. 11, No. 1, hal 63-74.

Kwiatkowski, D., Phillips, P. C. B., Schmidt, P., dan Shin, Y. 1992. Testing the Null Hypothesis of Stationarity Against the Alternative of a Unit Root, How Sure Are We that Economic Time Series Have a Unit Root. Journal of Econometrics, Vol. 54, hal 159-178.

Laux, P., Vogl, S., Qiu, W., Knoche, H. R., dan Kunstmann, H. 2011. Copula-based Statistical Refinement of Precipitation in RCM Simulations over Complex Terrain. Hydrology and Earth System Sciences, Vol. 15, hal 2401-2419.

Ljung, G. M. dan Box, G. E. P. 1978. On a Measure of Lack of Fit in Timeseries Models. Biometrika, Vol. 65, hal 297-303.

Rosadi, D. 2011. Analisis Ekonometrika \& Runtun Waktu Terapan dengan R (Aplikasi untuk Bidang Ekonomi, Bisnis, dan Keuangan). Yogyakarta: Andi Offset.

Sinay, L. J. dan Aulele, S. N. 2015. Rainfall and Number of Rainy Days Prediction in Ambon Island using Vector Autoregression Model. Ambon, Faculty of Mathemathics and Science, Universitas Pattimura, hal 90-98.

Sinay, L. J., Patty, H. W. M., dan Leleury, Z. A. 2016. Analisis Model Curah Hujan Di Kota Ambon Menggunakan Metode Box-Jenkins. Ambon, Fakultas Keguruan dan Ilmu Pendidikan; Universitas Pattimura, hal 176-196.

Sinay, L. J., Pentury, T., dan Anakotta, D. 2017. Peramalan Curah Hujan Di Kota Ambon menggunakan Metode Holt-Winters Exponential Smoothing. Barekeng: Jurnal Ilmu Matematika dan Terapan, Desember, Vol. 11, No. 2, hal 100-108.

Villarini, G., Smith, J. A., dan Napolitano, F. 2010. Nonstationary Modeling of Long Record of Rainfall and Temperature over Rome. Advances in Water Resources, Vol. 33, No. 10, hal 1256-1267.

Wang, W., Van Gelder, P. H. A. J. M., Vrijling, J. K., dan Ma, J. 2005. Testing and Modelling Autoregressive Conditional Heteroskedasticity of Streamflow Processes. Nonlinear Processes in Geophysics, Vol. 12, hal 55-66.

Yusof, F. dan Kane, I. L. 2013. Volatility Modeling of Rainfall Time Series. Theoretical and Applied Climatology, Vol. 113, No. 1-2, hal 247-258. 